\title{
The role of the epikarst in karst and cave hydrogeology: a review
}

\author{
Paul W. Williams ${ }^{1}$
}

\begin{abstract}
:
Williams P.W. 2008. The role of the epikarst in karst and cave hydrogeology: a review. International Journal of Speleology, 37 (1), 1-10. Bologna (Italy). ISSN 0392-6672.

The epikarst (also known as the subcutaneous zone) comprises highly weathered carbonate bedrock immediately beneath the surface or beneath the soil (when present) or exposed at the surface. Porosity and permeability are higher near the surface than at depth, consequently after recharge percolating rainwater is detained near the base of the epikarst, the detention ponding producing an epikarstic aquifer. Such an aquifer is found only where the uppermost part of the vadose zone is very weathered compared to the bedrock at depth. Sometimes this contrast in porosity and permeability does not occur either because the epikarst has been scraped off by glacial scour or because high porosity exists throughout the bedrock. In some conditions porosity may even diminish near the surface because of case-hardening. The epikarst is best developed in pure, crystalline limestones or marble where it is typically about $10 \mathrm{~m}$ thick. It then contains a suspended aquifer that is under-drained and sustains the distal tributaries of cave streams and small perennial flows emerging on hillsides (epikarstic springs). Slow leakage paths from the epikarst maintain seepage to many stalactites throughout the year. A distinction should be recognized between the location (and form) of the epikarst and the function of the epikarst, because the near surface zone in carbonate rocks does not always contain a suspended aquifer.
\end{abstract}

Keywords: epikarst, subcutaneous zone, hydrogeology, percolation

Received 29 August 2007; Revised 11 October 2007; Accepted 30 October 2007

\section{FORM AND FUNCTION OF THE EPIKARST}

The epikarst or subcutaneous zone is located at the top of the aerated or vadose zone in carbonate rocks. The vadose zone in karst comprises the soil (if there is any), the epikarst zone, and the transmission zone. From the epikarst, water percolates downwards through a zone dominated by transmission rather than storage that delivers recharge to the saturated or phreatic zone. In the sense of location, the epikarst is always present because it is the 'skin' of the karst; but in terms of hydrological function - the detention and storage of recharge from rainfall in a subsurface aquifer - the epikarst is often absent. These and other points were considered in the final discussion "What is Epikarst?" in Jones et al. (2004a). Although virtually all work on epikarst has been conducted on carbonate terrains, an epikarst aquifer may also exist in other karst rocks, such as gypsum, but has received little or no study. When subaerially exposed in arid or semi-arid climates, gypsum acquires a sealing crust from recrystallization following alternate wetting and drying (Klimchouk 1996, Macaluso \& Sauro 1996), not unlike the case-hardened crust acquired by calcareous aeolianites (Jennings 1968). Such crusts have little water storage capacity.

1 School of Geography, Geology \& Environmental Science, University of Auckland, PB 92019, Auckland, New Zealand. Email: p.williams@auckland.ac.nz
Present understanding of the epikarst stems from a convergence of ideas on its biological (Rouch, 1968) and hydrological function (Mangin, 1973, 1975; Bakalowicz et al., 1974) and its geomorphological role (Williams, 1972). Rouch recognised that a perched water body between caves and the surface was required for the maintenance of aquatic cave organisms that appeared in percolation water; Mangin named and defined the epikarst aquifer; Bakalowicz et al. identified its delaying function as recharge passed through the vadose zone following rain; and Williams recognised the significance of subcutaneous processes in the evolution of surface landforms, and later brought the hydrological and geomorphological ideas together (Williams, 1983, 1985). Further important contributions to our understanding were made by Smart \& Friederich (1987), Klimchouk (1987, 1995, 2000, 2004), Klimchouk et al. (1996), Perrin et al. (2003), Trcek (2003), Palmer (2004) and others (see contributors to Jones et al., 2004b). The evolution of concepts relating to the epikarst is discussed by Bakalowicz (2004) and Williams (2004) and a review of current understanding of its hydrological function and geomorphological significance is presented in Ford \& Williams (2007).

When present, the epikarst consists of a near surface zone of weathered limestone with high secondary porosity (10-30\%). It can outcrop directly 
at the surface or occur immediately beneath the soil. The epikarst gradually gives way to the main body of the vadose zone that comprises largely unweathered bedrock with a porosity that is usually $<2 \%$ in dense, crystalline limestones and is mainly provided by fissures. The high storage capacity, highly variable void distribution and spatially variable nature of water flow within the epikarst distinguishes it from the rest of the underlying vadose zone, which functions mainly as a transmission zone (Bakalowicz, 1995) with minimal storage. When developed to its fullest expression, which is in pure, dense limestone and marble, there is a strong contrast in porosity and permeability between that near the surface and that found at depth (Fig. 1). The epikarst is typically 3-10 $\mathrm{m}$ deep, but its characteristics can vary considerably according to lithology and geomorphological history, as emphasized by Klimchouk (2004). Sometimes there is little or no soil, for example in the arid zone and in glacially scoured regions. In many alpine areas, where the carbonate rock has been tectonically stressed and deformed during uplift and then later unloaded by rapid erosion and deep valley incision, fissures with relatively wide apertures can be even deeper, and the epikarst can extend to $30 \mathrm{~m}$ or more. Conditions are then favourable for the development of deep vertical shafts. As a result surface drainage is facilitated and there may be relatively little water storage capacity in the epikarst except under patches of karrenfeld, although there may be considerable seasonal storage of snow.
The high porosity and permeability of the epikarst arises from the fact that the greatest expenditure of chemical energy on the dissolution of carbonate rocks occurs near the surface, because of proximity to the main source of $\mathrm{CO}_{2}$ production in the soil. Ford \& Williams (2007) point out that about $70 \%$ of solutional denudation in a karst catchment is usually accomplished within the top $10 \mathrm{~m}$ or so of the limestone outcrop and the effectiveness of corrosional attack gradually diminishes with distance from the surface $\mathrm{CO}_{2}$ supply. The outcome of this is that the network of fissures through which percolation water passes is widened by dissolution near the surface, but the extent and frequency of widening diminishes gradually with depth. Solutionally enlarged joints taper downwards and become less numerous, as illustrated in Williams (1983). This can be readily observed in quarries (Fig. 2). A consequence of this is that permeability also diminishes with depth and a strong contrast in hydraulic conductivity develops between the near surface and the subsurface. Whereas relatively unweathered crystalline limestone typically has a porosity of $<2 \%$, that in the epikarst typically exceeds $20 \%$.

In spite of the above points, field observation shows that carbonate rocks do not always have a functioning epikarst. This is either because it has not developed or because it has been removed. Sometimes, for example, the weathered 'skin' of the karst has been scoured off by glaciation, which has eroded the pre-existing zone of high secondary porosity. Sometimes it has never

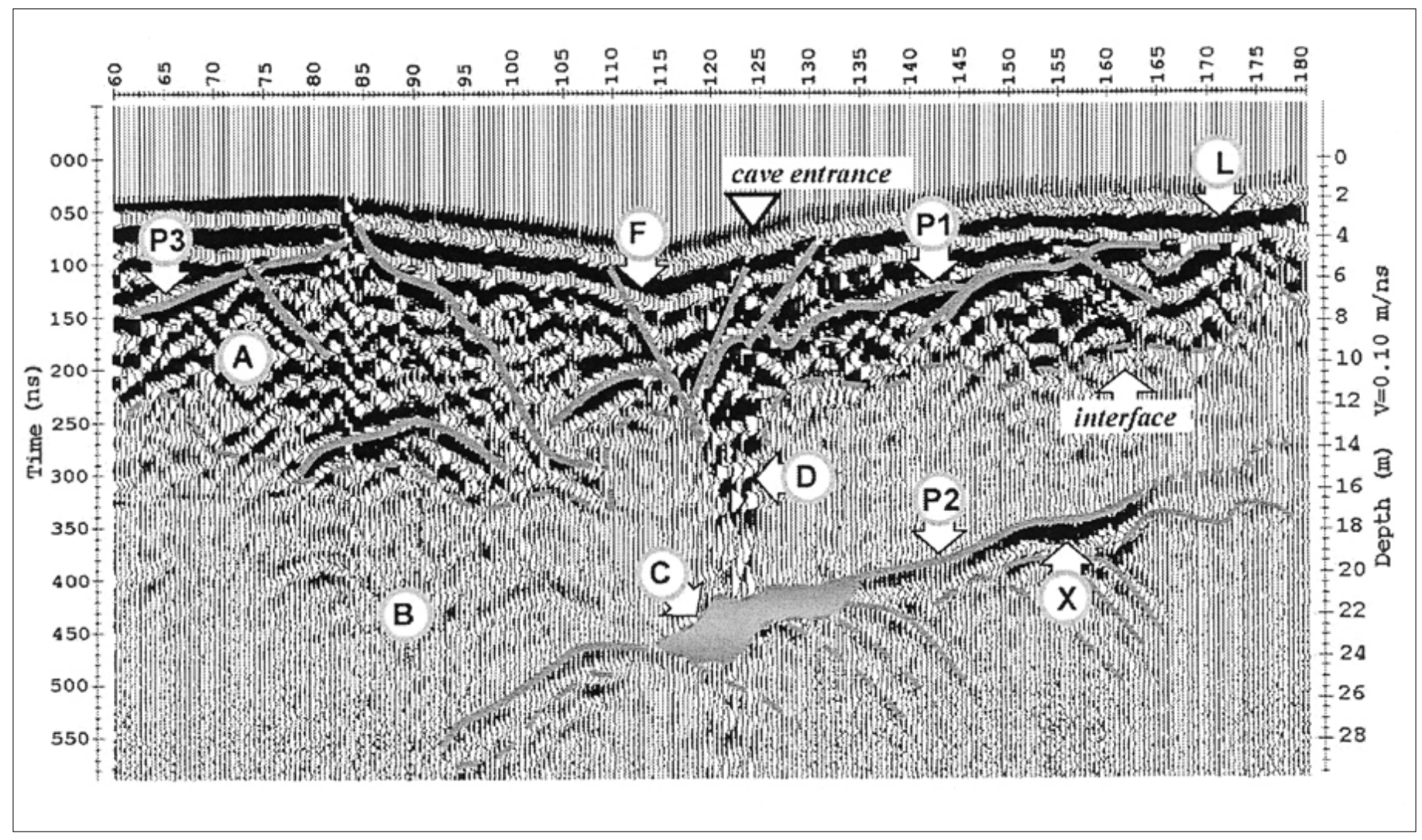

Fig. 1. Ground penetrating radar observations of the epikarst in the Lamalou district of southern France. In this example the 'interface' at the base of the epikarst can be seen to vary from about $8-16 \mathrm{~m}$ below the surface. A: fractured and karstified limestone in the epikarst; B: massive and compact limestone; C: Lamalou Cave; D: pothole inlet to cave; F: fault; L: karren; P1,2,3: bedding planes; X: unknown cave. (From Al-fares et al. 2002). 


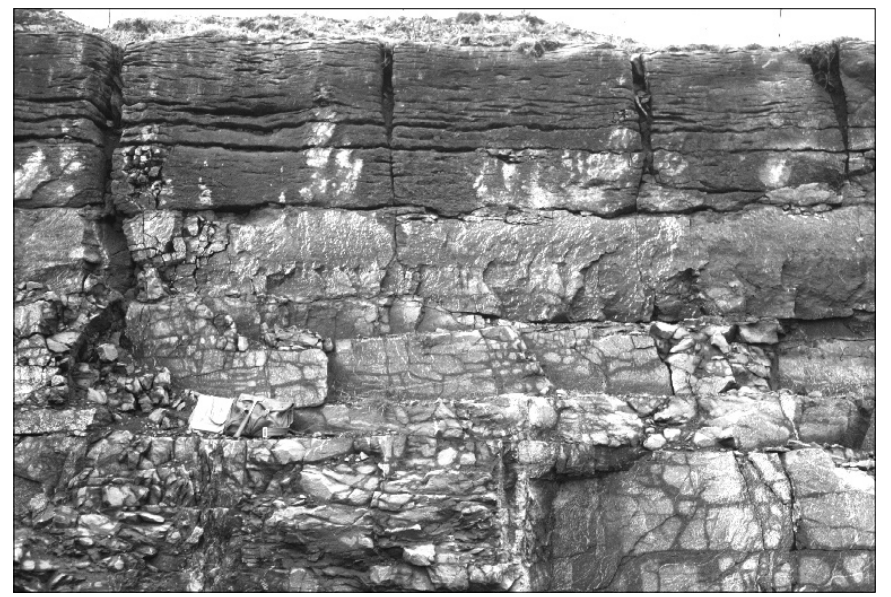

Fig. 2,A. Three examples showing variability in the epikarst.

A 3.5 metre high quarry section in Carboniferous Limestone from the Burren, western Ireland. Glaciation has stripped most of the epikarst, which at this site is only about $1 \mathrm{~m}$ deep.

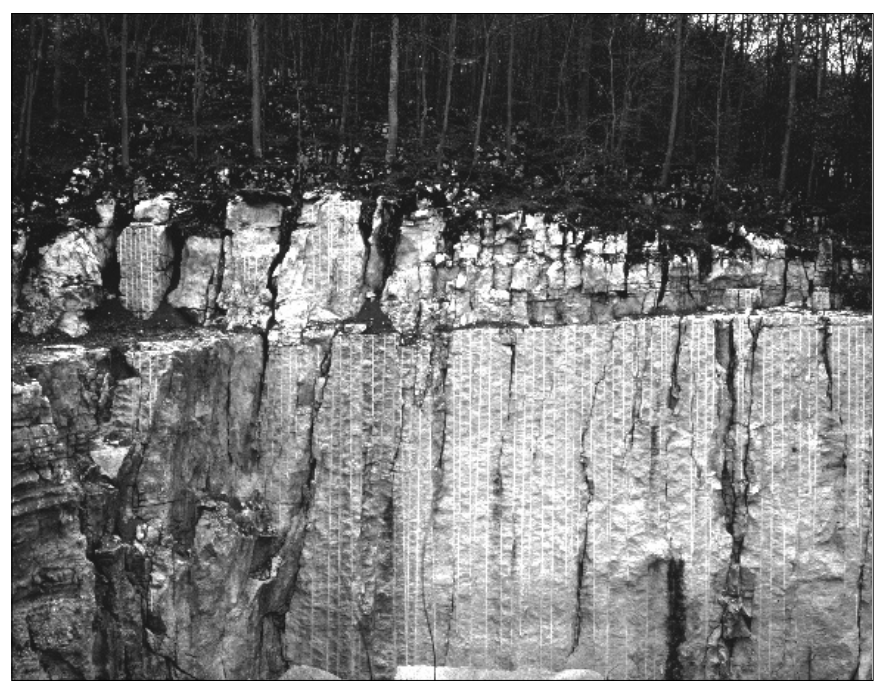

Fig. 2,B. Section through the epikarst beneath a forested slope in the Venetian Prealps, Italy. The quarry face shows solutionally widened joints to taper downwards and become less numerous with depth. The epikarst is several metres thick.

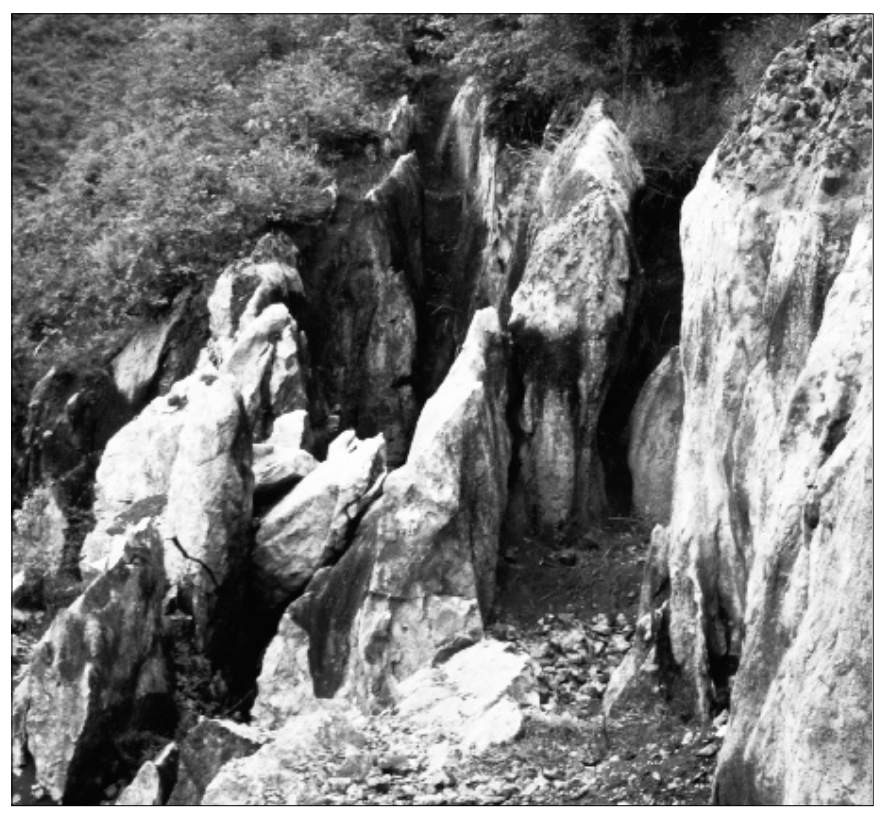

Fig. 2,C. Upper part of the epikarst beneath a cone karst slope in Guizhou, China. Solutionally widened joints contain residual clay soils that at this site have been removed by excavation. developed, as is often the case in limestones with high primary porosity, such as coral and chalk, where primary porosities can be $20-45 \%$ throughout the rock. In these porous carbonates, further enhancement of porosity near the surface sufficient to give rise to a strong contrast in permeability and storativity compared to the rock below is very uncommon. On the contrary, under tropical climatic conditions where wetting and drying cycles are common, the uppermost layers of chalky limestones and emerged coral reefs frequently have less porosity than further down in the vadose zone because of case-hardening; a consequence of secondary deposition of carbonate in primary pores immediately beneath the surface (Ireland, 1979). This effect is at its most extreme in aeolian calcarenites (carbonate dune limestones), as described by Jennings (1968), who gave excellent examples from Australia. Mylroie \& Vacher (1999) found that in such rocks case-hardening can reduce primary porosity near the surface by a factor of 10 or more.

The form of the epikarst illustrated in Figure 1 provides a model for what is normally conceptualised, but it does in fact vary considerably from place-toplace. The reason for this is that every karst has its unique combination of lithology, structure, geomorphological history and climate. The karst surface in the illustration (from the Hortus plateau in Mediterranean France) has low relief and thin patchy soil, with outcrops of karren and a few closed depressions. The epikarst is $8-16 \mathrm{~m}$ deep. This situation contrasts strongly with areas of intense surface dissection such the 'stone forest' regions of Mt. Api in Sarawak, Shilin in Yunnan, China, the tsingy of Madagascar, the labyrinth karst of Nahanni, Canada, the arête and pinnacle karst of Mt Kaijende in Papua New Guinea or the giant grikelands of the Kimberley Ranges in Western Australia. These areas have wide open joints that can be $10-100 \mathrm{~m}$ or more deep and several metres wide at the surface. Consequently, in these places the epikarst can also be very deep. However, sometimes (as at Shilin) the epikarst terminates at the water table with no intervening vadose transmission zone. In other places widened joints are deep, but are largely full of weathered residue such as porous dolomitic sand, as in parts of the Grands Causses of southern France (such as at Montpellier-le-Vieux). Elsewhere some karsts are thickly blanketed by weathering residues or allogenic deposits (e.g. alluvium, loess, tephra, etc), as in the Sinkhole Plain of Kentucky. And by contrast, in many karsts at high latitudes, great Pleistocene glaciers have stripped the soil and truncated the epikarst, reducing it in places to only a metre or so in thickness beneath a glacio-karstic pavement surface, as in parts of Manitoba, Ontario, and western Ireland.

The form and function of the epikarst, therefore, is very variable, largely because of the numerous factors that are involved in its development, as elaborated by Klimchouk (2004). The epikarst is the zone near the surface, but the hydrologically significant function of the epikarst aquifer can only occur in karst 
rocks in which subcutaneous dissolution has led to considerably enhanced secondary porosity, such that there is a strong permeability contrast between the epikarst zone and the transmission zone beneath.

\section{STORAGE, MIXING AND TRANSMISSION IN THE EPIKARST}

The variable characteristics of the epikarst described above strongly influence its capacity to absorb, store and transmit precipitation. Where the karst surface is largely bare, the uptake of water is determined by the characteristics of the rock (its vertical hydraulic conductivity); but where it is covered, it is controlled by the nature of the soil (its infiltration capacity). The storativity of the epikarst is determined by three factors: (1) the thickness and continuity of the epikarst, (2) its average porosity (these first two together determining the available storage space), and (3) the relative rate of inflow and outflow of water. The epikarst is like a colander: the capacity of the vessel to hold water is determined by the balance between the rate at which water comes in and the rate at which it drains. Whereas the average porosity is determined by the karst void space less the volume of granular fill, the drainage rate is controlled by the vertical hydraulic conductivity of the underlying transmission zone. This varies because of the uneven pattern of opened joints and faults and their variable permeability. Thus some epikarsts have a large storage potential but are rapid draining, others are frequently replenished by rain and are commonly near capacity, and some are low lying and often partly flooded by phreatic groundwaters.

Water tends to accumulate at the base of a well developed epikarstic zone, because the infiltration capacity at the surface is much greater than the rate of downwards percolation through the underlying transmission zone. The water cannot escape as freely as it got in and the excess recharge is stored in the void space of the epikarst, i.e. in the widened fissures and in the intergranular porosity of any soil they may contain. The recharge is literally held up - both detained and suspended - and it is this temporarily stored water that constitutes the epikarstic aquifer. It is perched above a leaky capillary barrier (Fig. 3). Its piezometric surface is drawn down over the main leakage paths afforded by shafts developed down major joints (Fig. 4) and the direction of subcutaneous flow is down the hydraulic gradient into enlarged fissures. It is evident, therefore, that the epikarst is under-drained. Solution dolines are a topographic manifestation of the focussing of flow and dissolution associated with this process (Williams 1983), and they penetrate most of the thickness of the epikarst.

Not all fissures are closed tight at the base of the epikarst; a few of them can be observed to penetrate as major openings right through the rock. As a result, these become the main drainage routes as water passes through the transmission zone. They act as the foci for centripetal flow paths that under-drain

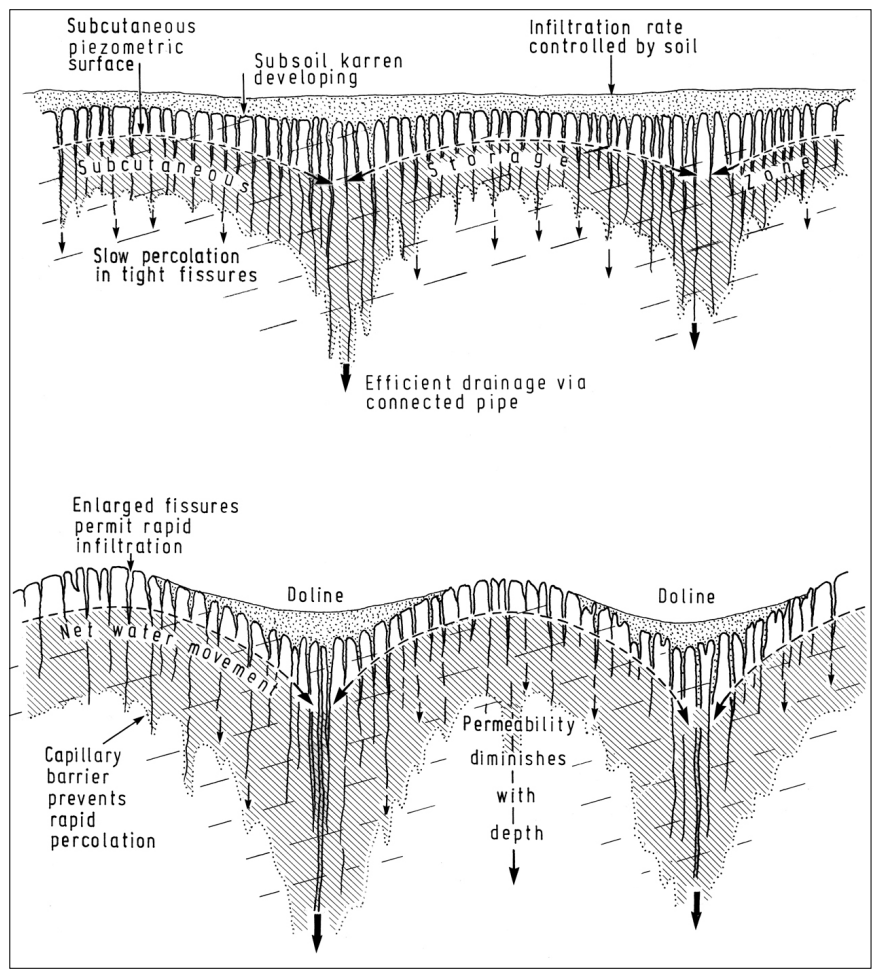

Fig. 3. Water stored in the subcutaneous zone constitutes an epikarstic aquifer that is perched above a leaky capillary barrier. Dolines gain topographic expression because of the focussing of flow and dissolution down major leakage paths (from Williams 1983)



Fig. 4. (a) Solution dolines are a topographic expression of sites of centripetal drainage through the epikarst. (b) Beneath the surface the subcutaneous water table marks the upper surface of the epikarst aquifer and is drawn down over the main leakage paths developed down major joints. (c) Drainage of the epikarst is focused by zones of high hydraulic conductivity. These sites are the headwaters of autogenic cave streams (from Williams 1985). 
the fissured epikarst. Developing ideas from work in the early 1980s in the USSR, Klimchouk (1995) and others explained how the concentration of flow at the base of the epikarst encourages the formation of shafts and, in a particularly well illustrated paper with convincing field evidence from the Sette Comuni Plateau in the Italian Pre-Alps, he and co-authors demonstrated the efficacy of the process (Klimchouk et al., 1996). Blind vertical shafts, sometimes known as domepits or avens, develop downwards from the base of the epikarst, and can eventually be exposed by collapse as the surface lowers. These sites of concentrated flow are the distal tributaries of drains through the vadose zone and are the main routes by which diffuse autogenic recharge is transmitted to conduits in the unsaturated zone and thence to the phreatic zone.

Heavy rainfall leads to surges of diffuse autogenic recharge and to pulses of percolation through the vadose zone (Williams 1993). The rising volume of water within the epikarst aquifer during storm (or snowmelt) events increases hydraulic head and so produces a pressure pulse that stimulates a transfer of water. This piston effect process is distinct from the transit of individual molecules of water through the system (Bakalowicz, 1995). These effects lead to different pulse-through and flowthrough times following a recharge event, the latter being significantly longer. The pressure pulse effect stimulated by rising head can cause percolation drips at stalactites to respond to rain within an hour or so (Fig. 5), whereas the associated flow-through time can be weeks to months, for example with spring snow-melt being pulsed out in late summer (Klimchouk \& Jablokova, 1989).

Flow-through time can be measured directly by dye tracing. Friederich \& Smart (1981) placed fluorescent dyes at several sites at the base of the soil above GB Cave in the Mendip Hills, England. Dye first appeared in the cave close to the injection site, but spread rapidly until most sites sampled in the cave were positive (Fig. 6). This demonstrated that lateral diffusion of dye occurred. Since some positive sample sites were $80 \mathrm{~m}$ laterally from the injection point and at a shallow depth, it was also evident that this diffusion took place within the top $10 \mathrm{~m}$ of the epikarst. The majority of the injected tracer was discharged as a high concentration pulse via shaft flow adjacent to the injection site, but part was still detectable elsewhere 13 months later. Under conditions of slow recharge, seepage inlets had the highest concentrations, but following increased recharge after rain, a sharp high concentration response was obtained again from shaft flow, thus indicating flushing from storage. At any particular time, concentrations varied significantly between adjacent inlets, indicating that they were not fed from a homogeneous store but from one that was imperfectly mixed.

Similar dye tracing experiments were conducted by Bottrell \& Atkinson (1992) in the Pennine karst in England. Four different fluorescent dyes were

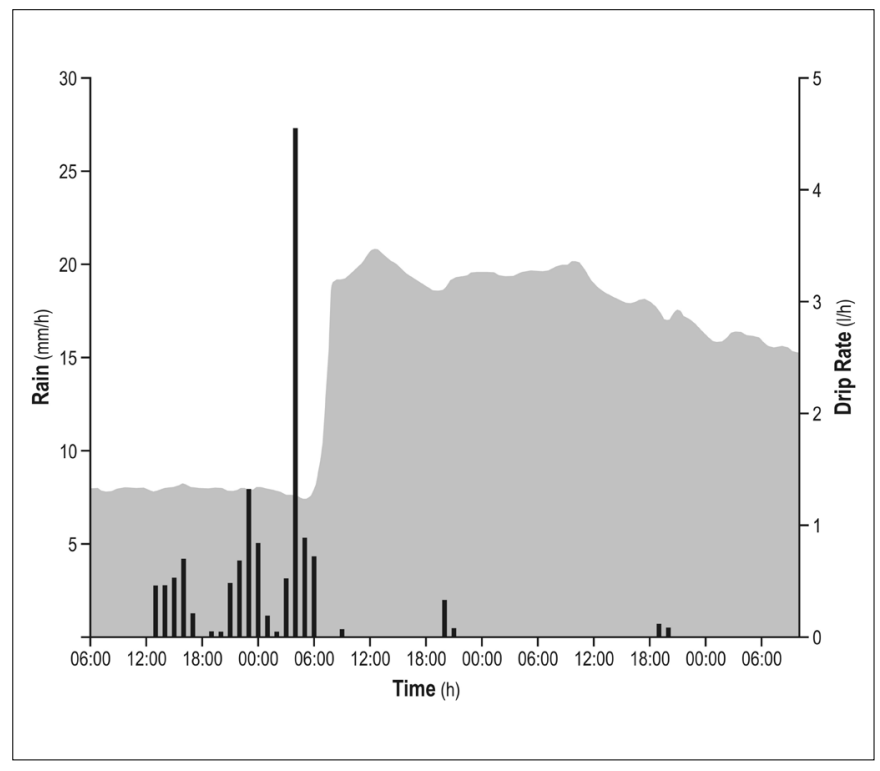

Fig. 5. The relationship between rainfall and percolation response in Aranui Cave, New Zealand. The cave is situated about $60 \mathrm{~m}$ beneath a slope covered with natural rainforest growing on a deep soil (details in Williams and Fowler 2002). The graph shows a three day interval. After a dry period in summer the first rains replenish interception, soil moisture and epikarstic storage, then a subsequent high intensity rainfall event provokes a rapid pulse-through response that is registered as a sharp increase in drip rate from a stalactite in the cave.

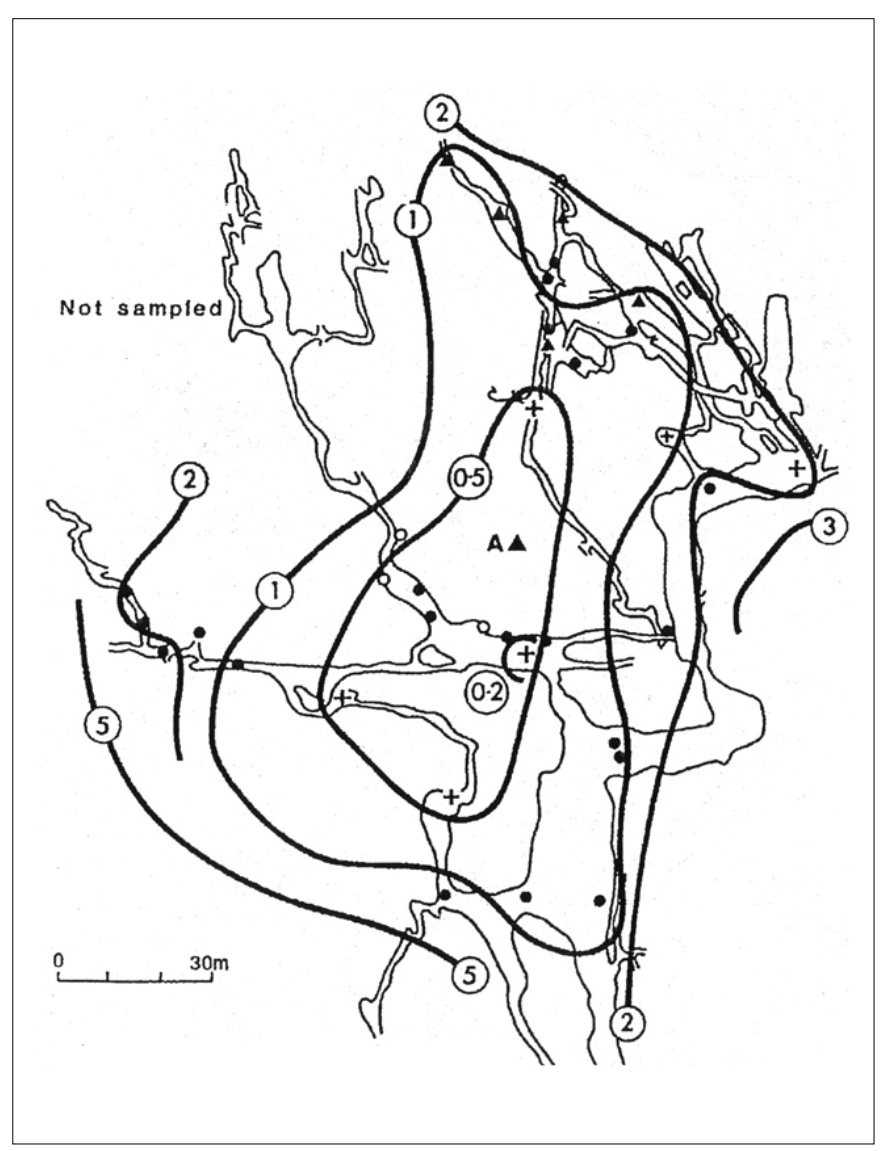

Fig. 6. Dispersal of fluorescent dye into GB Cave, England (from Friederich and Smart 1981). The dye was injected on the surface at the points marked with a cross + . Input points in the cave are shown by black dots $\cdot$. Contours depict first arrival times of dye in days in the cave. The dye arrived directly beneath the injection points within a few hours, but had spread laterally more than $60 \mathrm{~m}$ within 5 days. Diffusion within the epikarst is clearly indicated. 
placed beneath the soil above White Scar Cave, where 24 water inlets were monitored. Ten traces were performed from seven injection sites. Weather conditions ranged from extremely wet to very dry. The dyes traversed the $45-90 \mathrm{~m}$ thick vadose zone and were detected in the cave, sometimes within 24 hours. It was found that water did not necessarily flow to the closest inlet below the input point, but could appear over $100 \mathrm{~m}$ away without also appearing at inlets apparently below the intervening path. These observations suggested that flow in the unsaturated zone was through discrete systems of isolated fractures. However, what happened also depended on hydrological conditions, with greatly increased spatial dispersion of dye occurring during heavy rainfall, indicating lateral flow switching. Dye concentration at monitoring sites showed exponential decrease over time, as might be expected in a notional mixing tank. However, at some sites after rain, rather than being more diluted the dye concentration increased again, indicating a pulsed flushing effect from a dye store. This produced a 'saw-tooth' pattern of gradual decline in dye concentration over several months. Bottrell \& Atkinson (1992) deduced three components of flow: (i) rapid through-flow with a characteristic residence time of approximately 3 days; (ii) a component with short-term storage and residence time of 30-70 days; and (iii) a long-residence stored component with a characteristic time of 160 days or more. Storage components (ii) and (iii) were considered probably to be in water-filled voids. Those corresponding to type (ii) are flushed slowly and constantly, whereas those corresponding to type (iii) are only flushed for short periods during high states of flow when water (and dye) is released into type (ii) storage. Similar conclusions were reached by Kogovsek (1997) following dye tracing in the epikarst of Slovenia. Three flow components were recognised in the vadose zone: rapid flow-through with velocities from $0.5-2 \mathrm{~cm} \mathrm{~s}^{-1}$; slower velocities of the order of $10^{-2} \mathrm{~cm}$ $\mathrm{s}^{-1}$; and the slowest velocities of $<0.001 \mathrm{~cm} \mathrm{~s}^{-1}$.

Sometimes the behaviour of naturally occurring tracers such as environmental isotopes and trace elements illuminates processes in the epikarst. Bakalowicz \& Jusserand (1987) found from a comparison of $\delta^{18} \mathrm{O}$ values in precipitation and percolation waters that about 18 weeks was required for the transit of water through about $300 \mathrm{~m}$ of limestone above Niaux Cave in southern France. Using a similar method, Williams \& Fowler (2002) found a few months was required to transmit water through $60 \mathrm{~m}$ of vadose zone to a cave in New Zealand. In more arid zones transit time is longer. Using both stable isotopes and tritium in semi-arid New Mexico, Chapman et al. (1992) deduced flow rates of between 7 and $15 \mathrm{~m}$ year $^{-1}\left(4.8 \times 10^{-5} \mathrm{~cm} \mathrm{~s}^{-1}\right)$ through $250-300 \mathrm{~m}$ of vadose zone at Carlsbad Caverns. In another semiarid region, in Israel, Even et al. (1986) found isotopic homogenization to occur quickly after infiltration, but then some waters percolated rapidly while others were detained for decades in the epikarst.
Trace elements were used as natural tracers by Tooth \& Fairchild (2003), who investigated the chemistry of drip waters in a cave in western Ireland. They developed a series of plumbing diagrams from soil zone to bedrock to help explain the geochemical evolution of water during percolation. Variations of water chemistry with discharge were used to deduce the hydrogeochemical processes occurring in the unsaturated zone, and to shed light on whether increases in drip rate are a result of direct inflow of storm water from soil macropores or due to piston flow from epikarst storage. They concluded that karst water response to recharge is dictated by the flow route taken through the soil zone (in this case comprising glacial till), the contrast between soil matrix flow and well-connected macropore flow being particularly important, with soil matrix flow being the dominant water source during dry periods.

Tooth \& Fairchild's (2003) work brings the hydrological role of the soil over karst into focus, and again raises the question of whether most of the water that sustains percolation should be attributed to moisture stored in the soil or to water stored in the epikarst - an issue considered by Williams in 1983. It is well known that thick soils can have a large soil water storage capacity, but when percolation is sustained throughout a long dry season in sites with only thin or skeletal soils the predominant importance of epikarstic storage is unambiguous. This is the case, for example, in the semi-arid Carlsbad Cavern region in New Mexico (Williams, 1983; Chapman et al., 1992) and in a Brazilian site studied by Sondag et al. (2003). We also see percolation sustained in caves beneath alpine karrenfeld essentially devoid of soil. However, in most karsts water is stored in both the soil and the epikarst, with the two stores inter-digitating at the weathering front. Perrin et al. (2003) provide an interesting analysis into the relative role of soil cover and epikarst in a catchment in Switzerland. They note that although soil moisture storage may in their case amount to about $140 \mathrm{~mm}$, this volume is mainly stored in the soil matrix porosity and so does not contribute significantly to the dynamic storage, although it plays a role in mixing and controlling infiltration velocities. Most dynamic storage is located in the epikarst and it plays an important role in distributing infiltration towards the phreatic (saturated) zone.

Ford \& Williams (2007) point out that another problem that confronts us when trying to understand the operation of the epikarst (in all its varieties) is whether it is best described as a well mixed aquifer or a system of neighbouring but essentially separate compartments. They conclude that the evidence is contradictory. The distinctive geochemistry of percolation waters from different drip points in the same cave described by Tooth $\&$ Fairchild (2003) indicates that even if some mixing occurs it is incomplete, and the fact that separate 
flow paths can exist is demonstrated by the dye tracing experiments discussed earlier. Separate flow routes through the vadose zone are even sometimes orientated obliquely rather than vertically. But it has also been found that dye injected into the soil above a cave can spread and during wet conditions can appear at a wider range of percolation sites in a cave than during dry conditions. This implies that there is horizontal dispersal and mixing in the epikarst when the level of saturation rises during a wet period, probably by a process of lateral decanting (or flow switching) into adjacent voids, although the mixing and dispersal is still of limited extent. Other evidence goes very much further and suggests almost perfect mixing in some cases. This evidence comes from measurements of stable isotopes in percolation waters. Goede et al. (1982), Yonge et al. (1985), and Even et al. (1986) showed that $\delta^{18} \mathrm{O}$ values of cave drip waters, regardless of sample site in the cave, are very close to the average annual $\delta^{18} \mathrm{O}$ values of the regional rainfall. This indicates homogenisation of recharge waters in the stores and pathways that ultimately deliver water to underlying caves. In a more recent example from New Zealand, Williams \& Fowler (2002) found that while the $\delta^{18} \mathrm{O}$ of rainfall varied widely from month to month, the $\delta^{18} \mathrm{O}$ values of drips in a cave $60 \mathrm{~m}$ below the surface showed little variation over two years and were close in value to the average of the rainfall. In spite of that, the electrical conductivities of the cave drips were significantly different, indicating separate geochemical evolution within the percolation zone. Their drip rates and responsiveness to recharge also varied considerably.

This apparently conflicting evidence concerning hydrological processes in the epikarst could be resolved if most of the homogenisation of the stable isotope signal were to occur in the soil or in the most porous upper part of the epikarst before the recharge is captured in percolation cells or pathways through the lower epikarst, and before most geochemical evolution of percolation water in contact with limestone occurs. Since isotopic homogenisation can occur in epikarsts with very thin soils, it seems that the upper part of the epikarst can be the main homogenisation zone.

Storage volume and residence time in the epikarst is not easy to calculate. Ford \& Williams (2007) conclude that evidence from semi-arid karsts indicates that storage time in the epikarst can be of the order of years or even decades, although in humid zones storage time is usually much less, of the order of months to a year. After a long dry period the epikarst drains almost entirely, although it is evident from the surviving aquatic biota (Rouch 1968, Sket et al. 2004) that some water remains held by ponding in dissolution pockets and by capillary tension.

Smart \& Friederich (1987) estimated that in the epikarst of the Mendip Hills in England as much as $77 \%$ of annual recharge is transmitted via the highest capacity flow routes (shaft flow and subcutaneous flow), whereas only $23 \%$ percolates via the narrow low capacity seepage and vadose flow routes. They also suggested that vadose storage in the Mendip Hills could be as much as $49 \%$ of the total karst water stored, as compared to an earlier estimate based on spring flow separation of $11 \%$ for the same region by Atkinson (1977). In the Swabian Alb of southern Germany, Sauter (1992) subdivided the subcutaneous zone into fast and slow subsystems and estimated storage within each. He estimated fast subcutaneous storage (water that can be mobilized quickly within fractures and fissures) to vary between 0.3 and $2 \mathrm{~mm}$ with a possible maximum of $3 \mathrm{~mm}$, the subzone having a storage coefficient of approximately $0.1 \%$. This compared to slow subcutaneous storage where maximum stored quantities range between 20 and $30 \mathrm{~mm}$ and the storage coefficient is about $1 \%$.

The evolution of the epikarst and the transfer of water to the underlying phreatic zone have been modelled by Clemens et al. (1999). They showed that the development of karst conduits in the phreatic zone is partly dependent on the temporal evolution of the distribution of recharge from the epikarst. With the enlargement of paths of rapid percolation from the epikarst, the amount of undersaturated water flowing into the underlying conduit system increases, and hence the growth of phreatic conduits is accelerated. Kiraly (2002) and Kovács (2003) have shown how the epikarst and saturated zone can be integrated in computer models of karst hydrologic systems and, amongst other things, have demonstrated that the subcutaneous layer can modify the global hydraulic response of the entire system by decreasing its recession coefficient.

\section{CONCLUSIONS}

Various investigations have been made of water movement through the epikarst and vadose zone by following natural and artificial water tracers and by making observations in caves. These have been reviewed by Ford \& Williams (2007). We now recognise that water storage in the epikarst can be permanent enough to sustain aquatic biota and that leakage from it follows a range of paths from extremely slow seepages down capillary-sized openings to variable and sometimes high volume cascades down open shafts. Empiricalclassifications of transmission routes followed by vadose waters have been made by Gunn $(1981,1983)$, Friederich $\&$ Smart (1982) and Smart \& Friederich (1987) who reached complementary conclusions. They recognised (a) a spectrum of discharges from slow low volume seepages to variable, sometimes large, flows down open shafts, and (b) a range of discharge volumes and variabilities from almost unvarying low volume seepages to extremely variable flows that responded rapidly to recharge. These characteristics have since become better defined with improved instrumentation. Thus, for example, we now also know that high variability 
can occur at low discharge and that percolation from speleothems can be sensitive to air pressure changes (Genty \& Deflandre, 1998). Nevertheless, the interpretations made by Smart \& Friederich (1987) in their outstanding study of water movement and storage in the epikarst of the Mendip Hills in England remain valid, and their recognition of flow switching when recharge exceeds certain values and of non-linearity of percolation response has been confirmed by other workers (e.g. Baker et al., 2000; Baker \& Brunsdon, 2003; Sondag et al., 2003).

The considerable importance of the epikarst aquifer to karst hydrogeology as a whole is now well recognised. By detaining recharge it moderates floods and attenuates discharge. The suspended aquifer in the epikarst provides a habitat for permanent troglobitic aquatic fauna and a store of water that sustains percolation flow to speleothems in caves and to cave streams over extended dry periods. The aquifer is also appreciated as a significant source of water, many epikarst springs being tapped for local water-supply schemes, especially in China. It is also now recognised as a potential recipient of waste water discharges from the surface, including septic tank seepage; consequently the epikarst is now being factored into vulnerability assessments of available water resources (Doerflinger et al. 1999). But not all karsts have this suspended aquifer, in some young limestones the epikarst is characterised by a crust of secondary deposition of carbonate that provides a case-hardened lid on a cave, but not a source of water that sustains percolation and stream flow.

\section{ACKNOWLEDGEMENTS}

Drs A. Klimchouk and N. Goldscheider are thanked for their constructive reviews of the manuscript that included helpful suggestions that improved the value of the final paper.

\section{REFERENCES}

Al-fares W., Bakalowicz M., Guérin R. \& Dukhan M., 2002 - Analysis of the karst aquifer structure of the Lamalou area (Hérault, France) with ground penetrating radar. Journal of Applied Geophysics, 51: 97-106.

Atkinson T.C., 1977 - Diffuse flow and conduit flow in limestone terrain in the Mendip Hills, Somerset (Great Britain). Journal of Hydrology, 35: 93-110.

Bakalowicz M., 1995 - La zone d'infiltration des aquifères karstiques. Méthodes d'étude. Structure et fonctionnement. Hydrogéologie, 4: 3-21.

Bakalowicz M., 2004 - The epikarst. The skin of karst. In: Jones, W.K., Culver, D.C. \& Herman, J.S. (Eds.) - Epikarst. Special Publication 9. Charles Town, WV: Karst Waters Institute: 16-22.

Bakalowicz M., Blavoux B. \& Mangin A., 1974 - Apports du traçage isotopique naturel à la connaissance $d u$ fonctionnement d'un système karstique. Teneurs en oxygène 18 de trois systèmes des Pyrénées, France. Journal of Hydrology, 23: 141-158.
Bakalowicz M.J. \& Jusserand C., 1987 - Etude de l'infiltration en milieu karstique par les méthodes géochimiques et isotopiques. Cas de la Grotte de Niaux (Ariege, France). Bulletin Centre d'Hydrogeologie, Univ. Neuchatel, 7: 265-83.

Baker A., Genty D. \& Fairchild I. J., 2000 - Hydrological characterisation of stalagmite dripwaters at Grotte de Villars, Dordogne, by the analysis of inorganic species and luminescent organic matter. Hydrology and Earth System Sciences, 4(3): 439-49.

Baker A. \& Brunsdon C., 2003 - Non-linearities in drip water hydrology: an example from Stump Cross Caverns, Yorkshire. Journal of Hydrology, 277: 151-63.

Bottrell S.H. \& Atkinson T.C., 1992 -Tracer study and storage in the unsaturated zone of a karstic limestone aquifer. In: Hotzl, H. \& Werner, A. (Eds.) - Tracer Hydrology. Rotterdam: Balkema, 207-11.

Chapman J.B., Ingraham N.L. \& Hess J.W., 1992 Isotopic investigation of infiltration and unsaturated zone processes at Carlsbad Cavern, New Mexico. Journal of Hydrology, 133: 343-63.

Clemens T., Huckinghaus D., Liedl R. \& Sauter M., 1999 - Simulation of the development of karst aquifers: role of the epikarst. International Journal of Earth Sciences 88(1): 157-62.

Doerfliger N., Jeannin P.-Y., \& Zwahlen F., 1999 Water vulnerability assessment in karst environments: a new method of defining protection areas using a multi-attribute approach and GIS tools (EPIK method). Environmental Geology, 39(2): 165-76.

Even H., Carmi I., Magaritz M. \& Gerson R., 1986 Timing the transport of water through the upper vadose zone in a karstic system above a cave in Israel. Earth Surface Processes and Landforms, 11: 181-91.

Ford D.C. \& Williams P.W., 2007 - Karst Hydrogeology and Geomorphology. Chichester, Wiley: 561 pp.

Friederich H. \& Smart P.L., 1981 - Dye tracer studies of the unsaturated-zone recharge of the Carbonifereous Limestone aquifer of the Mendip Hills, England. Proceedings of the 8th International Congress of Speleology, 1: 283-6.

Friederich H. \& Smart P.L., 1982 - The classification of autogenic percolation waters in karst aquifers: a study in G.B. Cave, Mendip Hills, England. Proceedings of the University of Bristol Speleological Society, 16(2): 143-59.

Genty D. \& Deflandre G., 1998 - Drip flow variations under a stalactite of the Pere Noel cave (Belgium). Evidence of seasonal variations and air pressure constraints. Journal of Hydrology, 211(1-4): 20832.

Goede A., Green D.C. \& Harmon R.S., 1982 - Isotopic composition of precipitation, cave drips and actively forming speleothems at three Tasmanian cave sites. Helictite, 20, 17-29.

Gunn J., 1981 - Hydrological processes in karst depressions. Zeitschrift für Geomorphologie, NF, 25(3): 313-31.

Gunn J., 1983 - Point recharge of limestone aquifers - a model from New Zealand karst. Journal of Hydrology, 61: 19-29. 
Ireland P., 1979 - Geomorphological variations of 'case hardening' inPuerto Rico. Zeitschriftfür Geomorphologie, Supplement-Band, 32: 9-20.

Jennings J.N., 1968 - Syngenetic karst in Australia. In: Williams, P.W. \& Jennings, J.N. (Eds.) - Contributions to the Study of Karst. Publication G5, Research School for Pacific Studies, Australian National University, Canberra: 41-110.

Jones W.K., Culver D.C. \& Herman J.S., (Eds.), 2004 - What is Epikarst. In: Jones, W.K., Culver, D.C. \& Herman, J.S. (Eds.) - Epikarst. Charles Town, WV: Karst Waters Institute, Special Publication 9: $142-146$.

Jones W.K., Culver D.C. \& Herman J.S., (Eds.), 2004 - Epikarst. Charles Town, WV: Karst Waters Institute, Special Publication 9: 160 pp.

Kiraly L., 2002 - Karstification and groundwater flow. In: Gabrovsek, F. (Ed.), Evolution of Karst: from Prekarst to Cessation. Postojna-Ljubljana: Institut za raziskovanje krasa, ZRC SAZU: 155-90.

Klimchouk A.B., 1987 - Conditions and peculiarities of karstification into near surface zone of carbonaceous massives. Caves of Georgia, 11: 54-65. (Russian with English summary).

Klimchouk A.B., 1995 - Karst morphogenesis in the epikarstic zone. Cave and Karst Science, 21(2): 45-50.

Klimchouk A.B. 1996 - The dissolution and conversion of gypsum and anhydrite. International Journal of Speleology 25 (3-4): 21-36.

Klimchouk A.B., 2000 - The formation of epikarst and its role in vadose speleogenesis. In: Klimchouk, A.B., Ford, D.C., Palmer, A.N. \& Dreybrodt, W. (Eds.) Speleogenesis; Evolution of Karst Aquifers. Huntsville, AL: National Speleological Society of America: 91-99.

Klimchouk A.B., 2004 - Towards defining, delimiting and classifying epikarst: its origin, processes and variants of geomorphic evolution. In: Jones, W.K., Culver, D.C. \& Herman, J.S. (Eds.) - Epikarst. Special Publication 9. Charles Town, WV: Karst Waters Institute: 23-35.

Klimchouk A.B. \& Jablokova N.L., 1989 - Evidence of hydrological significance of the epikarstic zone from study of oxygen isotope composition of water, Arabika massif. Western Caucasus. Proceedings 10th International Congress of Speleology (Budapest), III: $798-799$.

Klimchouk A. B., Sauro U. \& Lazzarotto M., 1996 'Hidden' shafts at the base of the epikarstic zone: a case study from the Sette Communi plateau, Venetian Pre-Alps, Italy. Cave and Karst Science, 23(3):101-7.

Kogovsek J., 1997 - Water tracing tests in the vadose zone. In: Kranjc, A. (Ed.) - Tracer Hydrology 97. Rotterdam, Balkema: 167-72.

Kovács A., 2003 - Geometry and hydraulic parameters of karst aquifers: a hydrodynamic modeling approach. Faculté des Sciences, Université de Neuchâtel Thesis : $131 \mathrm{pp}$. [Available in pdf at www.unine.ch/biblio/]

Macaluso T. \& Sauro U. 1996 - Weathering crust and karren on exposed gypsum surfaces. International Journal of Speleology, 25(3-4): 115-26.

Mangin A., 1973 - Sur la dynamique des transferts en aquifère karstique. Proceedings of the 6 th International Congress of Speleology, Olomouc, CSSR, 6: 157-62.
Mangin A., 1975 - Contribution a l'étude hydrodynamique des aquifères karstiques. Univ. Dijon These Doct. es. Sci. [Annales de Spéléologie, 29(3): 283-332; 29(4): 495-601, 1974; 30(1) : $21-$ 124, 1975.]

Mylroie J.E. \& Vacher H.L., 1999 - A conceptual view of carbonate island karst. In: Palmer, A.N., Palmer, M.V. \& Sasowsky, I.D. (Eds.) - Karst Modelling. Charles Town, WV: Karst Waters Institute, Special Publication 5, 48-57.

Palmer A.N., 2004 - Growth and modification of epikarst. In: Jones, W.K., Culver, D.C. \& Herman, J.S. (Eds.) - Epikarst. Charles Town, WV: Karst Waters Institute, Special Publication 9: 56-61.

Perrin J., Jeannin P.-Y., \& Zwahlen F., 2003 - Epikarst storage in a karst aquifer: a conceptual model based on isotopic data, Milandre test site, Switzerland. Journal of Hydrology 279: 106-124.

Rouch R., 1968 - Contribution à la connaissance des Harpacticides hypogés (Crustacés, Copépodes). Annales de Spéléologie 23(1): 5-167.

Sauter M., 1992 - Quantification and forecasting of regional groundwater flow and transport in a karst aquifer. Tübinger Geowissenschaftlichen Abhandlungen, Reihe C, 13: 150 pp.

Sket B., Trontelj P., \& Zagar C. 2004 - Speleobiological characterization of the epikarst and its hydrological neighbourhood: its role in dispersion of biota, its ecology and vulnerability In: Jones, W.K., Culver, D.C. \& Herman, J.S. (Eds.) - Epikarst. Charles Town, WV: Karst Waters Institute, Special Publication 9: 104-113.

Smart P.L. \& Friederich H., 1987 - Water movement and storage in the unsaturated zone of a maturely karstified carbonate aquifer, Mendip Hills, England. Proceedings of Conference on Environmental Problems in Karst Terranes and their Solutions. National Water Well Association, Dublin, Ohio: 59-87.

Sondag F., van Ruymbeke M., \& Soubiès F., 2003 Monitoring present day climatic conditions in tropical caves using an Environmental Data Acquisition System (EDAS). Journal of Hydrology, 273(1-4): 103-18.

Tooth A.F. \& Fairchild I.J., 2003 - Soil and karst aquifer hydrologic controls on the geochemical evolution of speleothem-forming drip waters, Crag Cave, southwest Ireland. Journal of Hydrology, 273: 51-68.

Trcek B., 2003 - Epikarst zone and the karst aquifer behaviour: a case study of the Hubelj catchment, Slovenia. Ljubljana. Geološki zavod Slovenije: 100p.

Williams P.W., 1972 - Morphometric analysis of polygonal karst in New Guinea. Geological Society of America Bulletin, 83: 761-96.

Williams P.W., 1983 - The role of the subcutaneous zone in karst hydrology. Journal of Hydrology, 61: 45-67.

Williams P.W., 1985 - Subcutaneous hydrology and the development of doline and cockpit karst. Zeitschrift für Geomorphologie, 29(4): 463-82. 
Williams P.W., 1993 - Climatological and geological factors controlling the development of polygonal karst. Zeitschrift für Geomorphologie, Suppl.-Bd. 93, 159-173.

Williams P.W., 2004- The epikarst: evolution of understanding. In: Jones, W.K., Culver, D.C. \&Herman, J.S. (Eds.) - Epikarst. Charles Town, WV:KarstWaters Institute, SpecialPublication 9: $11-22$.
Williams P.W. \& Fowler A., 2002 - Relationship between oxygen isotopes in rainfall, cave percolation waters and speleothem calcite at Waitomo, New Zealand. New Zealand Journal of Hydrology, 41(1): 53-70.

Yonge C.J., Ford D.C., Gray J. \& Schwarcz H.P., 1985 Stable isotope studies of cave seepage water. Chemical Geology, 58: 97-105. 